\title{
Dental Composites - a Low-Dose Source of Bisphenol A?
}

\author{
Markéta ŠIMKOVÁ ${ }^{1,2^{*}}$, Antonín TICHÝ ${ }^{3^{*}}$, Michaela DUŠKOVÁ ${ }^{\mathbf{1}}$, Pavel BRADNA ${ }^{\mathbf{3}}$ \\ *These authors contributed equally to this work.
}

${ }^{1}$ Institute of Endocrinology, Prague, Czech Republic, ${ }^{2}$ University of Chemistry and Technology, Prague, Czech Republic, ${ }^{3}$ Institute of Dental Medicine, First Faculty of Medicine of the Charles University and General University Hospital, Prague, Czech Republic

Received March 24, 2020

Accepted April 27, 2020

\section{Summary}

Dental composite materials often contain monomers with bisphenol A (BPA) structure in their molecules, e.g. bisphenol-A glycidyl dimethacrylate (Bis-GMA). In this study, it was examined whether dental restorative composites could be a low-dose source of BPA or alternative bisphenols, which are known to have endocrine-disrupting effects. Bis-GMA-containing composites Charisma Classic (CC) and Filtek Ultimate Universal Restorative (FU) and "BPA-free" Charisma Diamond (CD) and Admira Fusion (AF) were examined. Specimens (diameter $6 \mathrm{~mm}$, height $2 \mathrm{~mm}$, $\mathrm{n}=5$ ) were light-cured from one side for $20 \mathrm{~s}$ and stored at $37^{\circ} \mathrm{C}$ in methanol which was periodically changed over 130 days to determine the kinetics of BPA release. BPA concentrations were measured using a dansyl chloride derivatization method with liquid chromatography - tandem mass spectrometry detection. The amounts of BPA were expressed in nanograms per gram of composite $(\mathrm{ng} / \mathrm{g})$. BPA release from Bis-GMA-containing CC and FU was significantly higher compared to "BPA-free" CD and AF. The highest 1-day release was detected with FU $(15.4 \pm 0.8 \mathrm{ng} / \mathrm{g})$, followed by CC $(9.1 \pm 1.1 \mathrm{ng} / \mathrm{g}), \mathrm{AF}(2.1 \pm 1.3 \mathrm{ng} / \mathrm{g})$, and $\mathrm{CD}$ $(1.6 \pm 0.8 \mathrm{ng} / \mathrm{g})$, and the release gradually decreased over the examined period. Detected values were several orders of magnitude below the tolerable daily intake $(4 \mu \mathrm{g} / \mathrm{kg}$ body weight/day). Alternative bisphenols were not detected. BPA was released even from "BPA-free" composites, although in significantly lower amounts than from Bis-GMA-containing composites. Despite incubation in methanol, detected amounts of BPA were substantially lower than current limits suggesting that dental composites should not pose a health risk if adequately polymerized.

\section{Key words}

Bisphenol A • Dental Composite • Liquid Chromatography • Mass Spectrometry • Release

\section{Corresponding authors}

A. Tichý, Institute of Dental Medicine, First Faculty of Medicine of the Charles University and General University Hospital, Karlovo náměstí 32, Prague, 121 11, Czech Republic. E-mail: antonin.tichy@lf1.cuni.cz

M. Šimková, Institute of Endocrinology, Národní 8, Prague, 116 94, Czech Republic. E-mail: msimkova@endo.cz

\section{Introduction}

Bisphenol A (BPA, 2,2-bis(4-hydroxyphenyl) propane) is known for its capability of interfering with hormonal system, thus being termed an endocrine disruptor (Diamanti-Kandarakis et al. 2009). The estrogen-like effects of BPA have been known for a long time (Fleisch et al. 2010), but BPA is also able to bind to other types of receptors, such as androgen, thyroid, or glucocorticoid (Kolatorova Sosvorova et al. 2017, Vandenberg et al. 2009). Therefore, its potential negative effects were examined in many studies which proved BPA harmful in animal models. In humans, causality can hardly be proven, but strong associations were found between exposure to BPA and reproductive, developmental, metabolic and other disorders (Rochester 2013, Kolatorova et al. 2017, Kolatorova et al. 2018a, Kolatorova et al. 2018b, Vitku et al. 2018). As a consequence, the use of BPA has been limited, and BPA has been replaced in some products by its structural analogues, e.g. bisphenol S (BPS), bisphenol F (BPF) or bisphenol AF (BPAF) (Fig. 1) whose use has not been regulated. However, the metabolism and mechanism of action of BPS and BPF are similar to BPA, resulting in comparable endocrine-disruptive effects (Eladak et al. 
2015, Rochester and Bolden 2015). BPAF is considered even more damaging than BPA due to its higher electronegativity and reactivity of the $\mathrm{CF}_{3}$ moiety (Yang et al. 2012).<smiles>CC(C)(c1ccc(O)cc1)c1ccc(O)cc1</smiles>

bisphenol A<smiles>O=S(=O)(c1ccc(O)cc1)c1ccc(O)cc1</smiles>

bisphenol S<smiles>Oc1ccc(Cc2ccc(O)cc2)cc1</smiles>

bisphenol F<smiles>Oc1ccc(C(c2ccc(O)cc2)(C(F)(F)F)C(F)(F)F)cc1</smiles>

bisphenol AF

Fig. 1. Bisphenol $A$ and some of its industrially used structural analogues.

BPA is a building block of polycarbonates and is contained in epoxy resins and in other synthetic polymerbased materials. They are widely used as wrappings in food industry, so the dietary intake contributes to daily BPA exposure. Among other sources, the ingestion of dust, dermal absorption of BPA from thermal paper, or release from dental restorative materials are commonly mentioned in the literature (Geens et al. 2012). The tolerable daily intake (TDI) has been set to $50 \mu \mathrm{g} / \mathrm{kg}$ body weight, but the European Food Safety Authority (EFSA) has temporarily reduced it to $4 \mu \mathrm{g} / \mathrm{kg}$ body weight in 2015 (EFSA Panel on Food Contact Materials and
Processing 2015). Although EFSA estimated that the daily BPA exposure for adults is $1.449 \mu \mathrm{g} / \mathrm{kg}$ body weight, some studies suggest that the dose-response relationship is nonmonotonic (Diamanti-Kandarakis et al. 2009, Vandenberg et al. 2012); therefore, concerns about long-term low-dose exposure to BPA remain (Birnbaum 2012, vom Saal and Hughes 2005).

While BPA is not a constituent of most dental materials, resin-based materials contain monomers derived from BPA, e.g. Bis-GMA (bisphenol A glycidyl dimethacrylate), Bis-EMA (ethoxylated bisphenol A glycol dimethacrylate), or Bis-DMA (bisphenol A dimethacrylate) (Fig. 2). As a consequence, BPA may be present in these materials in trace amounts as a contaminant from the manufacturing process (Fig. 3), or a degradation product of the monomer hydrolysis (Löfroth et al. 2019, Soderholm and Mariotti 1999, Van Landuyt et al. 2011). Several studies confirmed the release of BPA from dental materials, but the amounts varied greatly (Löfroth et al. 2019), probably due the lack of standard methodology and different types of materials tested. However, it was revealed that monomers with ether linkage of BPA, such as Bis-GMA and Bis-EMA which are used in restorative resin composites and adhesive systems, are less prone to hydrolytic degradation than those with ester bond to BPA like Bis-DMA contained in dental sealants (Fleisch et al. 2010, Löfroth et al. 2019, Schmalz et al. 1999).<smiles>C=C(C)C(=O)OCC(O)COc1ccc(C(C)(C)c2ccc(OCC(O)COC(=O)C(=C)C)cc2)cc1</smiles><smiles>C=C(C)C(=O)OCCOCCOCCOC(=O)C(=C)C</smiles><smiles>C=C(C)C(=O)OCCOc1ccc(C(C)(C)c2ccc(OCCOC(=O)C(=C)C)cc2)cc1</smiles><smiles>C=C(C)C(=O)Oc1ccc(C(C)(C)c2ccc(OC(=O)C(=C)C)cc2)cc1</smiles><smiles>C=C(C)C(=O)OCCOC(=O)NCCC(C)CC(C)(C)CNC(=O)OCCOC(=O)C(=C)C</smiles><smiles>C=CC(=O)OCCOC(=O)NCC1CC2CC1C1CCC2C1CNC(=O)OCCOC(=O)C=C</smiles>

Fig. 2. Dental methacrylate monomers. Bis-GMA is the most common monomer in dental restorative composites, Bis-EMA is its ethoxylated derivative. Bis-DMA is used in dental sealants. TEGDMA, UDMA and TCD-DI-HEA are included as examples of bisphenol-A free monomers used in dental composites. Bis-GMA - bisphenol A glycidyl dimethacrylate, Bis-EMA - ethoxylated bisphenol A glycol dimethacrylate, Bis-DMA - bisphenol A dimethacrylate, TEGDMA - triethylene glycol dimethacrylate, UDMA - urethane dimethacrylate, TCD-DI-HEA - bis(acryloyloxymethyl) tricyclo [5.2.1.02,6] decane. 
<smiles>C=C(C(=O)OCC1CO1)C(=O)OCC1CO1</smiles><smiles>C=C(C)C(=O)OCC(O)COc1ccc(C(C)(C)c2ccc(OCC(O)COC(=O)C(=C)C)cc2)cc1</smiles>

Fig. 3. Synthesis of bisphenol A glycidyl dimethacrylate (Bis-GMA).

In reaction to concerns about the leakage of BPA from dental materials, some "BPA-free" alternatives were introduced. In this study, the release of BPA from two conventional Bis-GMA-containing and two "BPA-free" restorative resin-based composites, which are commonly used as tooth-colored filling materials, was examined using liquid chromatography - tandem mass spectrometry (LC-MS/MS). Derivatization with dansyl chloride (Kolatorova Sosvorova et al. 2017) was used in order to increase sensitivity and enable the detection of eventual trace amounts of BPA in materials labeled as "BPA-free". Besides BPA, it was investigated whether alternative bisphenols BPS, BPF, and BPAF were present. Previous studies showed that more BPA was released to organic solutions, so methanol was selected as the elution medium to simulate the worst-case scenario. To determine the kinetics of the release, methanol was periodically changed over the period of 130 days. The null hypotheses tested were 1) that there would be no significant difference in the release of BPA between Bis-GMAcontaining and "BPA-free" composites, and 2) that alternative bisphenols would not be detected.

\section{Methods}

The resin-based composites tested in this study included Bis-GMA-containing Charisma Classic (CC; Kulzer, Hanau, Germany) and Filtek Ultimate Universal Restorative (FU; 3M, St. Paul, MN, USA), and "BPA-free" Charisma Diamond (CD; Kulzer, Hanau, Germany) and Admira Fusion (AF; Voco, Cuxhaven, Germany). The composites were of A2 shade except for FU whose shade was A2 Dentin. The overview of their compositions is presented in Table 1. Standards of BPA, BPS, BPF, BPAF and deuterated standard of BPA (d16BPA) were purchased from Sigma-Aldrich (St. Louis, MO, USA) as well as acetone, sodium bicarbonate, ammonium formate and dansyl chloride. Standard of deuterated BPS (d4BPS) was synthesized as described in Kolatorova Sosvorova et al. (2017). Diethylether, LC-MS grade methanol and water for chromatography were from Merck AG (Darmstadt, Germany). Methanol p.a. was purchased from Lach-Ner (Neratovice, Czech Republic).

\section{Specimen preparation}

Cylindrical specimens $(6 \mathrm{~mm}$ diameter, $2 \mathrm{~mm}$ thickness, surface area $94 \mathrm{~mm}^{2}, \mathrm{n}=5$ ) were prepared in PTFE (polytetrafluoroethylene) molds placed on a glass slide. The materials were applied in one increment, covered with another glass slide to create a flat surface and prevent oxygen inhibition of polymerization, and lightcured from one side for $20 \mathrm{~s}$ using the LED polymerization lamp Valo (Ultradent Products, South Jordan, UT, USA) in the "standard" mode $\left(1000 \mathrm{~mW} / \mathrm{cm}^{2}\right)$.

Thirty minutes after polymerization, specimens were pushed out of the molds and transferred to glass test tubes with $2 \mathrm{ml}$ of LC-MS grade methanol. The tubes were closed using caps with PTFE septa and incubated at $37^{\circ} \mathrm{C}$. Methanol was changed after $1,4,9,16,35,65$, and 130 days to determine the kinetics of bisphenol release. Eluates were poured into new glass test tubes, and test tubes with specimens were rinsed with $0.5 \mathrm{ml}$ of methanol five times. Then, $2 \mathrm{ml}$ of methanol were added, and the test tubes were placed to the incubator. To avoid potential contamination, only glass and metal instruments repeatedly rinsed with methanol were used. 
Table 1. Composition of materials used in this study.

\begin{tabular}{|c|c|c|}
\hline $\begin{array}{l}\text { Composite material } \\
\text { (abbreviation) }\end{array}$ & $\begin{array}{l}\text { Manufacturer } \\
\text { (batch number) }\end{array}$ & Composition \\
\hline Charisma Classic (CC) & $\begin{array}{l}\text { Kulzer, Hanau, } \\
\text { Germany (K010733) }\end{array}$ & $\begin{array}{l}\text { Bis-GMA, TEGMA, Ba-Al-F glass fillers, pre-polymerized } \\
\text { filler, pyrogenic silica, initiator }\end{array}$ \\
\hline $\begin{array}{l}\text { Filtek Ultimate Universal } \\
\text { Restorative (FU) }\end{array}$ & $\begin{array}{l}\text { 3M, St. Paul, MN, } \\
\text { USA (N985020) }\end{array}$ & $\begin{array}{l}\text { Bis-GMA, Bis-EMA, UDMA, TEGDMA, PEGDMA, } \\
\text { non-agglomerated/non-aggregated silica and zirconia filler, } \\
\text { aggregated zirconia/silica cluster filler, initiator }\end{array}$ \\
\hline Charisma Diamond (CD) & $\begin{array}{l}\text { Kulzer, Hanau, } \\
\text { Germany (K010073) }\end{array}$ & $\begin{array}{l}\text { TCD-DI-HEA, UDMA, TEGDMA, Ba-Al-F glass fillers, } \\
\text { pyrogenic silica, initiator }\end{array}$ \\
\hline Admira Fusion (AF) & $\begin{array}{l}\text { Voco, Cuxhaven, } \\
\text { Germany (1919447) }\end{array}$ & $\begin{array}{l}\text { no conventional methacrylate monomers, "organically modified } \\
\text { ceramics" resin, glass ceramic filler, nano filler, initiator }\end{array}$ \\
\hline
\end{tabular}

Bis-GMA - bisphenol A glycidyl dimethacrylate, TEGDMA - triethylene glycol dimethacrylate, Bis-EMA - ethoxylated bisphenol A glycol dimethacrylate, UDMA - urethane dimethacrylate, PEGDMA - polyethylene glycol dimethacrylate, TCD-DI-HEA - bis(acryloyloxymethyl) tricyclo $[5.2 .1 .02,6]$ decane.

\section{LC-MS/MS analysis}

The calibration mixture was prepared by diluting methanol stock solutions of BPA, BPS, BPF and BPAF in methanol. A nine-point calibration curve in the range $0.032-8.0 \mathrm{ng} / \mathrm{ml}$ was constructed. The mixture of internal standards, also in methanol, contained d16BPA and d4BPS.

A methanol extract of each sample $(700 \mu l)$ was spiked with $10 \mu 1$ of internal standard (IS) mixture and evaporated to dryness under reduced pressure. Quality control samples with known addition of individual analyte as well as calibration curve samples were treated the same way. The derivatization reaction was conducted according to Kolatorova Sosvorova et al. (2017) and Vitku et al. (2015). Briefly, $50 \mu 1$ of dansyl chloride in acetone $(1 \mathrm{mg} / \mathrm{ml})$ and $50 \mu \mathrm{l}$ of $100 \mathrm{mM}$ sodium bicarbonate buffer were added to dry residues, vortexed and evaporated under reduced pressure. The dry residues were subsequently reconstituted in $300 \mu 1$ of methanol and equally diluted with $10 \mathrm{mM}$ aqueous solution of ammonium formate. $50 \mu \mathrm{l}$ were injected and analyzed by LC-MS/MS.

LC-MS/MS was performed using API 3200 (Sciex, Concord, Canada), a triple stage quadrupole mass spectrometer with electrospray ionization (ESI) connected to ultra-high performance liquid chromatograph (UPLC) Eksigent ultraLC 110 system (Redwood City, CA, USA). Chromatographic separation was performed using a Kinetex $\mathrm{C} 18 \quad 1.7 \mu \mathrm{m}$ $(150 \times 3.0 \mathrm{~mm})$ column (Phenomenex, Torrance, CA, USA) equipped with a security guard at a flow rate $0.4 \mathrm{ml} / \mathrm{min}$ at $50^{\circ} \mathrm{C}$. A mixture of methanol and water was used as a mobile phase. For detailed information about LC-MS/MS conditions, please refer to Kolatorova Sosvorova et al. (2017), Vitku et al. (2015). The lower limit of quantification (LLOQ) was $0.042 \mathrm{ng} / \mathrm{ml}$ for BPA, $0.055 \mathrm{ng} / \mathrm{ml}$ for BPS, $0.044 \mathrm{ng} / \mathrm{ml}$ for $B P F$, and $0.151 \mathrm{ng} / \mathrm{ml}$ for BPAF.

\section{Results}

BPA was detected in all eluates, whereas alternative bisphenols BPS, BPF, and BPAF were not detected in any of them. Mean concentrations of BPA in eluates $(\mathrm{ng} / \mathrm{ml})$ and amounts of BPA released per gram of composite $(\mathrm{ng} / \mathrm{g})$ are presented in Table 2 and Table 3, respectively. Figure 4 shows average daily BPA release in $\mathrm{ng} / \mathrm{g}$ while cumulative curves in Figure 5 illustrate the proportions of total released amount at each time period.

BPA release from Bis-GMA-containing CC and FU was significantly higher compared to "BPA-free" $C D$ and AF. All materials exhibited the largest BPA release during the first day, with the highest amount released from FU $(15.4 \pm 0.8 \mathrm{ng} / \mathrm{g})$, followed by CC $(9.1 \pm 1.1 \mathrm{ng} / \mathrm{g})$, $\mathrm{AF}(2.1 \pm 1.3 \mathrm{ng} / \mathrm{g})$, and $\mathrm{CD}(1.6 \pm 0.8 \mathrm{ng} / \mathrm{g})$. Figure 4 illustrates that the average daily elution gradually decreased towards zero over the examined period except for $\mathrm{FU}$, where the elution continued at a steady rate between days 4 and 130. In the case of AF, mean concentrations of released BPA were around or below LLOQ in eluates collected after 9, 16, 35, 65, and 130 days. The highest total amounts of BPA were released from $\mathrm{FU}(182.6 \pm 6.0 \mathrm{ng} / \mathrm{g})$, followed by $\mathrm{CC} \quad(146.3 \pm 7.0 \quad \mathrm{ng} / \mathrm{g}), \quad \mathrm{CD} \quad(8.3 \pm 1.5 \mathrm{ng} / \mathrm{g}), \quad$ and AF $(5.2 \pm 1.3 \mathrm{ng} / \mathrm{g})$. 


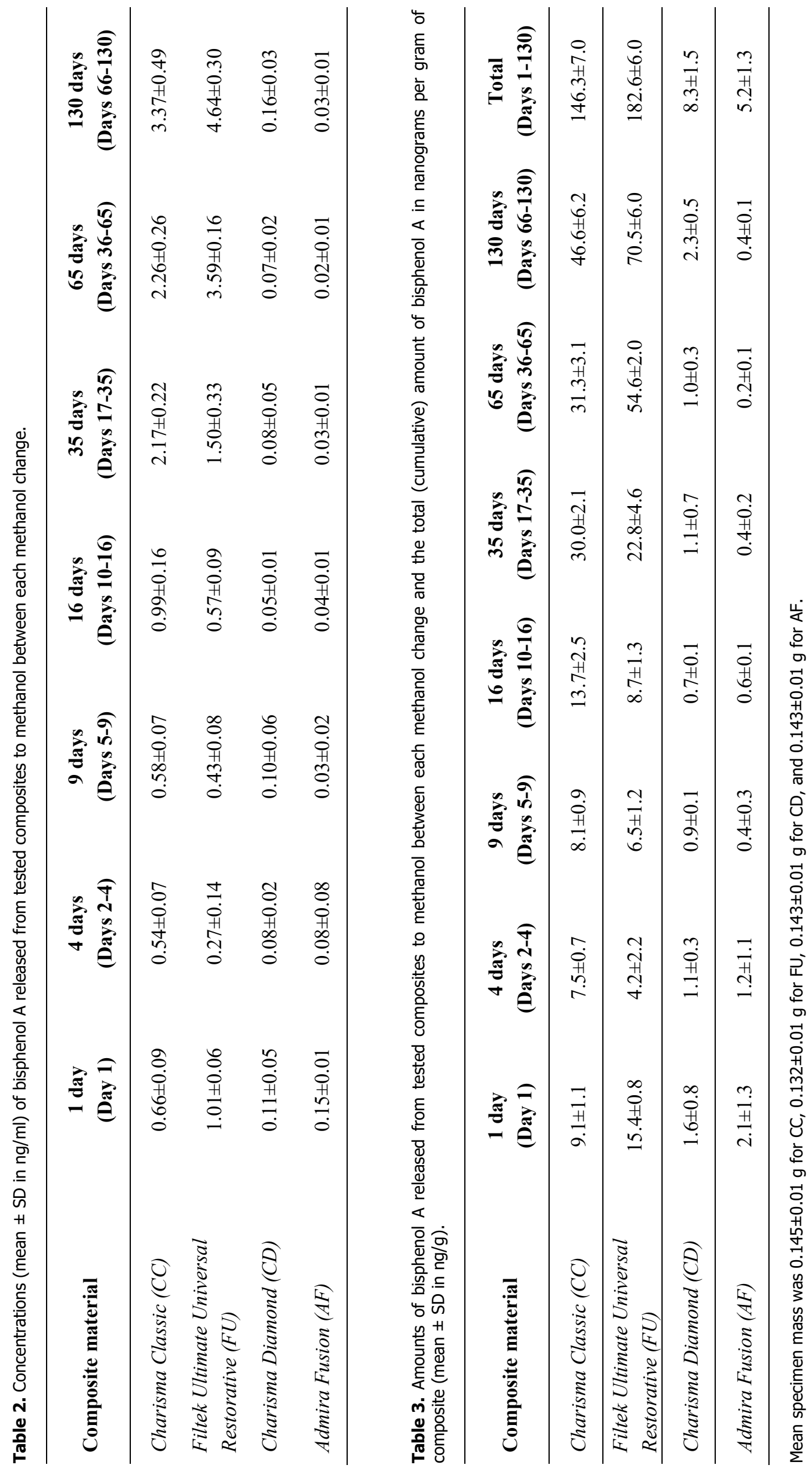



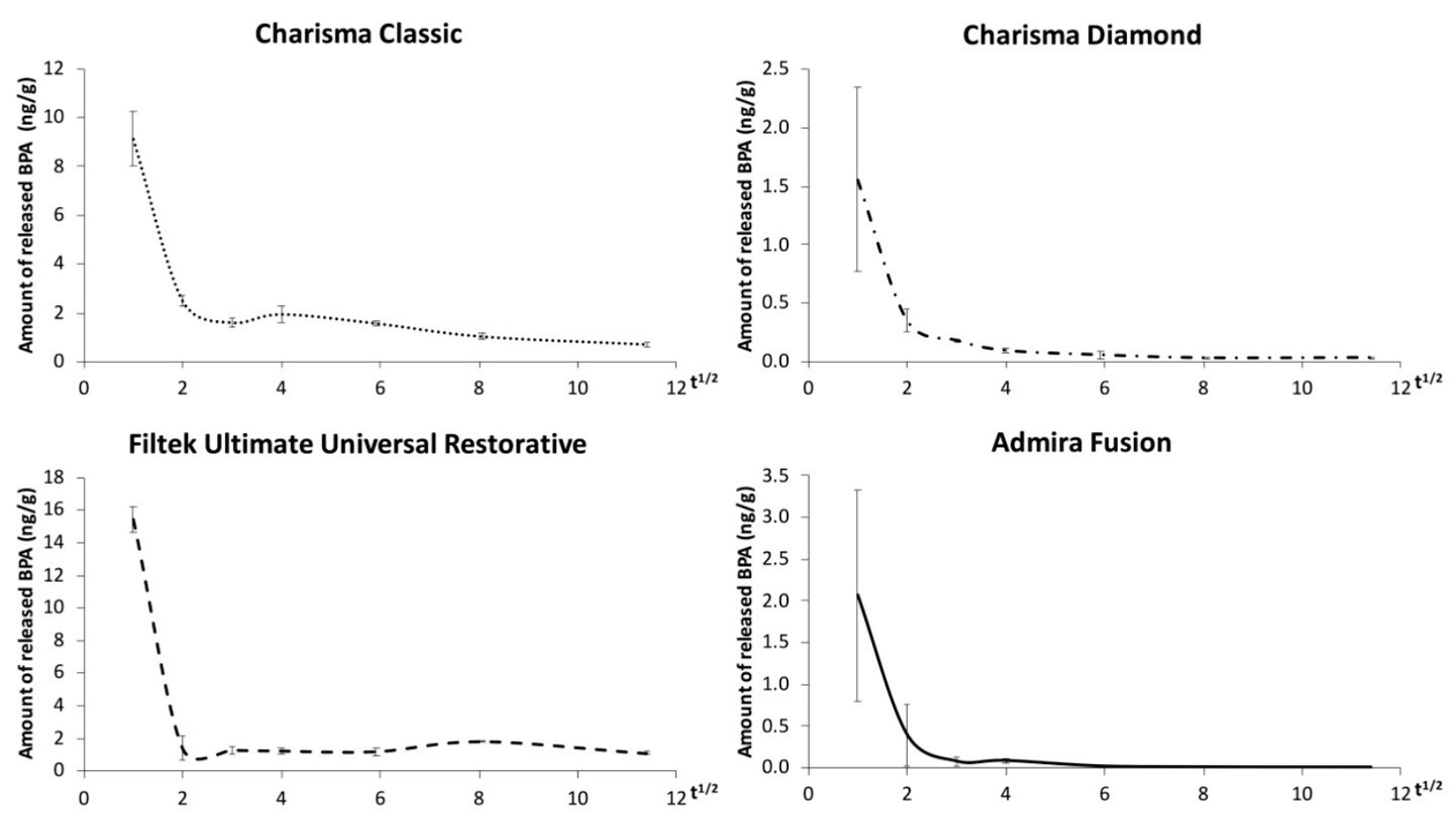

Material comparison

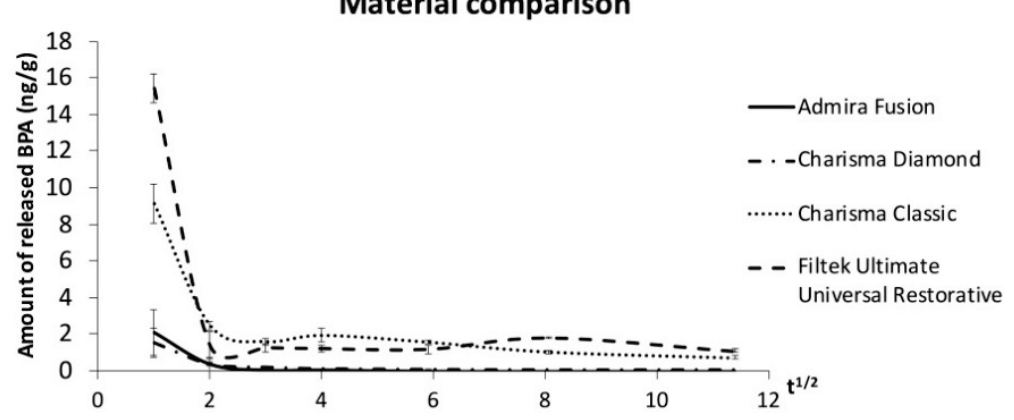

Fig. 4. Average daily release of bisphenol A per gram of composite $(\mathrm{ng} / \mathrm{g})$ plotted against the square root of time. The highest BPA release was observed after 1 day and a gradual decrease in daily released amount of BPA followed over the examined period except for Filtek Ultimate Universal Restorative, where the elution continued at a steady rate between days 4 and 130.

\section{Discussion}

The release of BPA from dental materials has been assessed in many studies using various analytical methods, mostly HPLC or gas chromatography mass spectrometry (Löfroth et al. 2019). However, the amounts of released BPA may often range around or below their quantification limit, which may lead to inaccurate and unreliable results. Moreover, the specificity of these methods may be insufficient, so other leached compounds might confound the results (Hope et al. 2016, Noda et al. 1999). Therefore, UPLC-MS/MS was used in two recent studies for its higher sensitivity and specificity. Their lower limits of quantification (LLOQ) were $0.1 \mathrm{ng} / \mathrm{ml}$ (Becher et al. 2018) and $0.25 \mathrm{ng} / \mathrm{ml}$ (De Nys et al. 2018), respectively, much lower than those of previous studies reviewed by Löfroth et al. (2019). The latter study used derivatization with pyridine-3-sulfonyl chloride to improve the detection sensitivity (De Nys et al. 2018). In this study, a previously validated LC-MS/MS method using derivatization with dansyl chloride (Kolatorova Sosvorova et al. 2017, Vitku et al. 2015) was applied. As a result, the LLOQ of BPA was $0.042 \mathrm{ng} / \mathrm{ml}$, allowing for a very sensitive determination of BPA levels even in the "BPA-free" materials. Besides that, the method also enables a sensitive detection of alternative bisphenols BPS, BPF, and BPAF, which have not been examined in dentistry to date.

BPA was detected in all eluates, but Bis-GMAcontaining composites $\mathrm{FU}$ and $\mathrm{CC}$ released significantly higher amounts of BPA than "BPA-free" materials. Therefore, the first null hypothesis had to be rejected. All composites exhibited the highest release during the first day, presumably due to the rapid penetration of methanol 

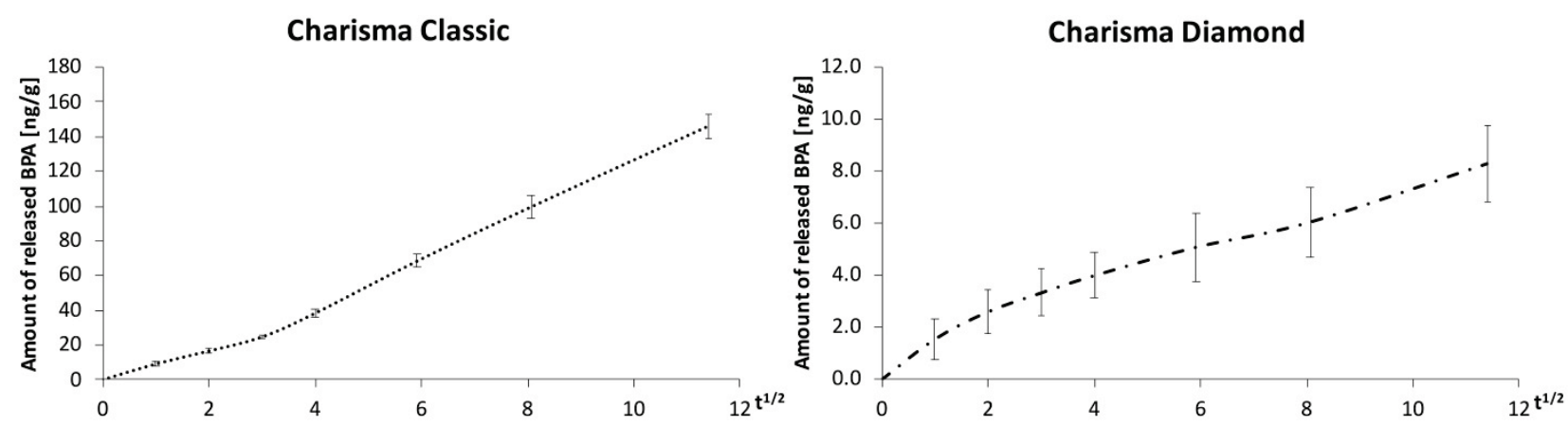

Filtek Ultimate Universal Restorative
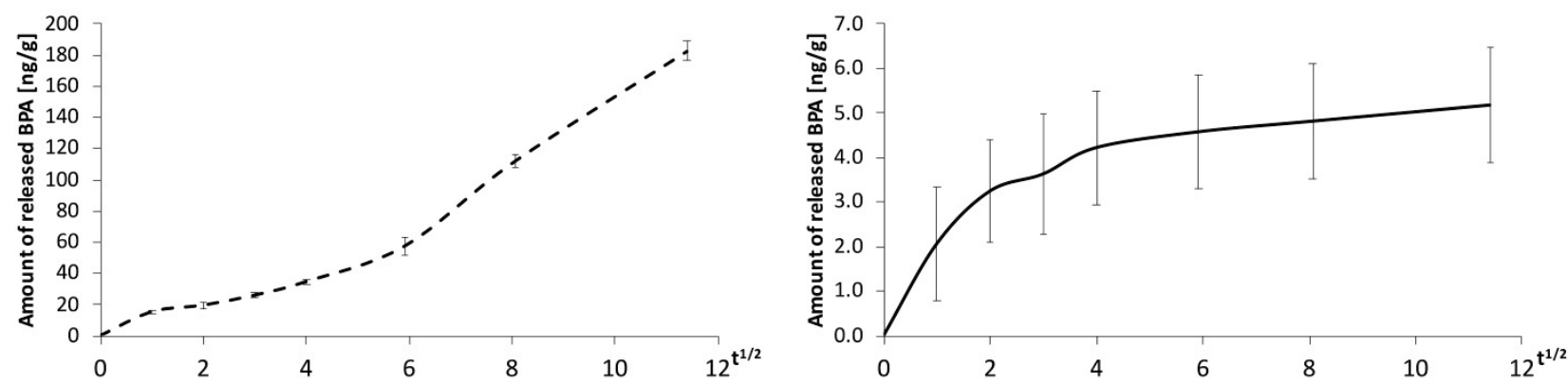

Material comparison

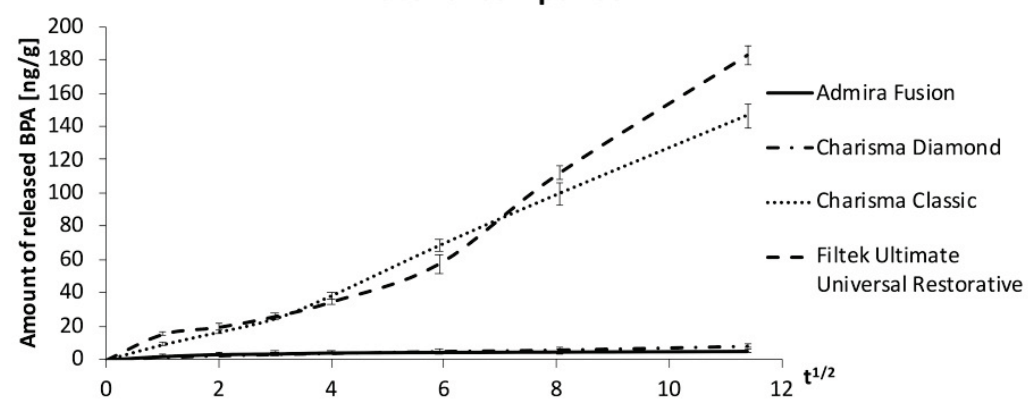

Fig. 5. Cumulative release of bisphenol $A$ per gram of composite $(\mathrm{ng} / \mathrm{g})$ plotted against the square root of time. The cumulative amounts of released BPA increased over the examined period. In the case of Admira Fusion, the plateau suggests that the release almost reached its maximum. In contrast, the cumulative curves of other materials indicate that the release would continue beyond the examined period, although at a gradually decreasing rate.

in the composites enabling the release of BPA from their structure. In the Bis-GMA-containing composites, the not entirely polymerized and easily soluble surface layer could contribute to the high initial BPA release, although glass slides were used to prevent oxygen inhibition of the free radical polymerization. The fast release of BPA during the first day could also be related to the fact that the degree of conversion (DC) of the composites was not final before they were immersed in methanol. The postirradiation polymerization (Leung et al. 1983, Pilo and Cardash 1992) is ongoing at a relatively high rate during the first hours after light-curing, and the gradual increase in DC could slow down the release of BPA. In "BPA-free" materials, the released BPA is presumably a contaminant from the manufacturing process.

Compared to previous studies of light-cured dental composites incubated in methanol (Durner et al. 2011, Imai and Komabayashi 2000), significantly lower amounts of released BPA were detected in this study. Presumably, this could be caused by differences in specimen preparation and analytical methods. Durner et al. (2011) used GC/MS, Imai and Komabayashi (2000) used HPLC, and neither of the studies mentioned the quantification limit. On the other hand, no release of BPA from Filtek Supreme XT (3M, Seefeld, Germany) to $75 \%$ ethanol was detected in a LC-MS/MS study (Polydorou et al. 2009). This does not indicate that no BPA was released, but rather that its levels could be below the LLOQ $0.5 \mu \mathrm{g} / \mathrm{ml}$ of the method used. In the two recent studies using UPLC-MS/MS, composites containing BPA-derived monomers incubated in artificial saliva (De Nys et al. 2018) and deionized water (Becher 
et al. 2018) mostly exhibited a slightly lower leakage of BPA compared to Bis-GMA-containing composites tested in our study. This could be attributed to the fact that the amounts of BPA released to water-based media are significantly lower compared with organic media (Van Landuyt et al. 2011).

In this study, the average daily release of BPA decreased markedly after the first day and was steadily decreasing over the 130-day period. This finding is in agreement with previous in vitro studies which examined the kinetics of BPA release (De Nys et al. 2018, Imai and Komabayashi 2000, Polydorou et al. 2009). However, long-term release was examined only by Polydorou et al. (2009) who did not detect any BPA after 1-year storage in $75 \%$ ethanol, probably due to the insuffiecient detection sensitivity (LLOQ $0.5 \mu \mathrm{g} / \mathrm{ml}$ ). The average daily release of BPA after day 4 did not surpass $2 \mathrm{ng} / \mathrm{g}$ of Bis-GMA-containing composites and $0.2 \mathrm{ng} / \mathrm{g}$ of "BPA-free" composites. While there are concerns about long-term low-dose exposure to BPA (Birnbaum 2012, vom Saal and Hughes 2005), these values appear to be only a negligible contribution to the daily exposure of $1.449 \mu \mathrm{g} / \mathrm{kg}$ body weight estimated by EFSA.

Alternative bisphenols were not detected in any of the eluates tested, so the second null hypothesis had to be accepted. The use of alternative bisphenols is not common in dentistry, because BPA-derived monomers can be replaced by BPA-free ones, although their physico-mechanical properties might be slightly different. This is in contrast with industry where BPA is an indispensable constituent of various polymers and cannot be easily eliminated, leading to the substitution with its analogues to achieve "BPA-free" products.

This study confirmed that BPA may be released from dental composites; however, the amounts were several orders of magnitude lower than TDI despite the use of methanol for incubation. De Nys et al. (2018) stated that the total exposed surface area of full crown restorations of all teeth is $7,372 \mathrm{~mm}^{2}$, so even in this worst-case scenario, $159 \mathrm{ng}$ of BPA could be released from FU during the first day. For a $70-\mathrm{kg}$ person, that equals to approximately $0.06 \%$ of TDI and $0.16 \%$ of the estimated daily exposure. The released amounts of BPA further decreased over the incubation period of 130 days. Based on the results of this study and the other recent UPLC-MS/MS studies (Becher et al. 2018, De Nys et al. 2018), it seems that the amounts of BPA released from light-cured resin composites may be lower than previously reported. Although studies evaluating the association between BPA release from dental composites and its adverse effects on human health are scarce, it appears that the contribution of contemporary restorative composites to the daily BPA exposure is only minor if they are properly polymerized.

\section{Conflict of Interest}

There is no conflict of interest.

\section{Acknowledgements}

The study was supported by Charles University, project PROGRES Q29/1LF and MH CZ - DRO (Institute of Endocrinology, 00023761). The authors would like to thank Jana Vitku and Lucie Kolatorova for their help with the application of the LC-MS/MS method.

\section{References}

BECHER R, WELLENDORF H, SAKHI AK, SAMUELSEN JT, THOMSEN C, BØLLING AK, KOPPERUD HM: Presence and leaching of bisphenol a (BPA) from dental materials. Acta Biomater Odontol Scand 4: 56-62, 2018. https://doi.org/10.1080/23337931.2018.1476869

BIRNBAUM LS: Environmental chemicals: evaluating low-dose effects. Environ Health Perspect 120: A143-A144, 2012. https://doi.org/10.1289/ehp.1205179

DE NYS S, PUTZEYS E, VERVLIET P, COVACI A, BOONEN I, ELSKENS M, VANOIRBEEK J, GODDERIS L, VAN MEERBEEK B, VAN LANDUYT KL, DUCA RC: A novel high sensitivity UPLC-MS/MS method for the evaluation of bisphenol A leaching from dental materials. Sci Rep 8: 6981, 2018. https://doi.org/10.1038/s41598-018-24815-Z

DIAMANTI-KANDARAKIS E, BOURGUIGNON J-P, GIUDICE LC, HAUSER R, PRINS GS, SOTO AM, ZOELLER RT, GORE AC: Endocrine-disrupting chemicals: an Endocrine Society scientific statement. Endocr Rev 30: 293-342, 2009. https://doi.org/10.1210/er.2009-0002 
DURNER J, STOJANOVIC M, URCAN E, SPAHL W, HAERTEL U, HICKEL REICHL F-X: Effect of hydrogen peroxide on the three-dimensional polymer network in composites. Dent Mater 27: 573-580, 2011. https://doi.org/10.1016/j.dental.2011.02.013

EFSA PANEL ON FOOD CONTACT MATERIALS AND PROCESSING: Scientific opinion on the risks to public health related to the presence of bisphenol A (BPA) in foodstuffs. EFSA J 13: 3978, 2015. https://doi.org/10.2903/j.efsa.2015.3978

ELADAK S, GRISIN T, MOISON D, GUERQUIN MJ, N'TUMBA-BYN T, POZZI-GAUDIN S, BENACHI A, LIVERA G, ROUILLER-FABRE V, HABERT R: A new chapter in the bisphenol A story: bisphenol S and bisphenol $F$ are not safe alternatives to this compound. Fertil Steril 103: 11-21, 2015. https://doi.org/10.1016/j.fertnstert.2014.11.005

FLEISCH AF, SHEFFIELD PE, CHINN C, EDELSTEIN BL, LANDRIGAN PJ: Bisphenol A and related compounds in dental materials. Pediatrics 126: 760-768, 2010. https://doi.org/10.1542/peds.2009-2693

GEENS T, AERTS D, BERTHOT C, BOURGUIGNON J-P, GOEYENS L, LECOMTE P, MAGHUIN-ROGISTER G, PIRONNET A-M, PUSSEMIER L, SCIPPO M-L, VAN LOCO J, COVACI A: A review of dietary and non-dietary exposure to bisphenol-A. Food Chem Toxicol 50: 3725-3740, 2012. https://doi.org/10.1016/j.fct.2012.07.059

HOPE E, REED DR, MOILANEN LH: Potential confounders of bisphenol-A analysis in dental materials. Dent Mater 32: 961-967, 2016. https://doi.org/10.1016/j.dental.2016.05.001

IMAI Y, KOMABAYASHI T: Elution of bisphenol A from composite resin: a model experiment. Dent Mater J 19: 133-138, 2000. https://doi.org/10.4012/dmj.19.133

KOLATOROVA L, DUSKOVA M, VITKU J, STARKA L: Prenatal exposure to bisphenols and parabens and impacts on human physiology. Physiol Res 66 (Suppl 3): S305-S315, 2017. https://doi.org/10.33549/physiolres.933723

KOLATOROVA L, SRAMKOVA M, VITKU J, VCELAK J, LISCHKOVA O, STARKA L, DUSKOVA M: Parabens and their relation to obesity. Physiol Res 67 (Suppl 3): S465-S472, 2018a. https://doi.org/10.33549/physiolres.934004

KOLATOROVA L, VITKU J, VAVROUS A, HAMPL R, ADAMCOVA K, SIMKOVA M, PARIZEK A, STARKA L, DUSKOVA M: Phthalate metabolites in maternal and cord plasma and their relations to other selected endocrine disruptors and steroids. Physiol Res 67 (Suppl 3): S473-S487, 2018 b. https://doi.org/10.33549/physiolres.933962

KOLATOROVA SOSVOROVA L, CHLUPACOVA T, VITKU J, VLK M, HERACEK J, STARKA L, SAMAN D, SIMKOVA M, HAMPL R: Determination of selected bisphenols, parabens and estrogens in human plasma using LC-MS/MS. Talanta 174: 21-28, 2017. https://doi.org/10.1016/j.talanta.2017.05.070

LEUNG RL, FAN PL, JOHNSTON WM: Post-irradiation polymerization of visible light-activated composite resin. J Dent Res 62: 363-365, 1983. https://doi.org/10.1177/00220345830620031201

LÖFROTH M, GHASEMIMEHR M, FALK A, VULT VON STEYERN P: Bisphenol A in dental materials - existence, leakage and biological effects. Heliyon 5: e01711, 2019. https://doi.org/10.1016/j.heliyon.2019.e01711

NODA M, KOMATSU H, SANO H: HPLC analysis of dental resin composites components. J Biomed Mater Res 47: 374-378, 1999. https://doi.org/10.1002/(SICI)1097-4636(19991205)47:3<374::AID-JBM12>3.0.CO;2-7

PILO R, CARDASH HS: Post-irradiation polymerization of different anterior and posterior visible light-activated resin composites. Dent Mater 8: 299-304, 1992. https://doi.org/10.1016/0109-5641(92)90104-K

POLYDOROU O, KÖNIG A, HELLWIG E, KÜMMERER K: Long-term release of monomers from modern dentalcomposite materials. Eur J Oral Sci 117: 68-75, 2009. https://doi.org/10.1111/j.1600-0722.2008.00594.X

ROCHESTER JR: Bisphenol A and human health: a review of the literature. Reprod Toxicol 42: 132-155, 2013. https://doi.org/10.1016/j.reprotox.2013.08.008

ROCHESTER JR, BOLDEN AL: Bisphenol S and F: a systematic review and comparison of the hormonal activity of bisphenol A substitutes. Environ Health Perspect 123: 643-650, 2015. https://doi.org/10.1289/ehp.1408989

SCHMALZ G, PREISS A, ARENHOLT-BINDSLEV D: Bisphenol-A content of resin monomers and related degradation products. Clin Oral Investig 3: 114-119, 1999. https://doi.org/10.1007/s007840050088

SODERHOLM KJ, MARIOTTI A: BIS-GMA-based resins in dentistry: are they safe? J Am Dent Assoc 130: 201-209, 1999. https://doi.org/10.14219/jada.archive.1999.0169 
VAN LANDUYT KL, NAWROT T, GEEBELEN B, DE MUNCK J, SNAUWAERT J, YOSHIHARA K, SCHEERS H, GODDERIS L, HOET P, VAN MEERBEEK B: How much do resin-based dental materials release? A meta-analytical approach. Dent Mater 27: 723-747, 2011. https://doi.org/10.1016/j.dental.2011.05.001

VANDENBERG LN, MAFFINI MV, SONNENSCHEIN C, RUBIN BS, SOTO AM: Bisphenol-A and the great divide: a review of controversies in the field of endocrine disruption. Endocr Rev 30: 75-95, 2009. https://doi.org/10.1210/er.2008-0021

VANDENBERG LN, COLBORN T, HAYES TB, HEINDEL JJ, JACOBS DR JR, LEE DH, SHIODA T, SOTO AM, VOM SAAL FS, WELSHONS WV, ZOELLER RT, MYERS JP: Hormones and endocrine-disrupting chemicals: low-dose effects and nonmonotonic dose responses. Endocr Rev 33: 378-455, 2012. https://doi.org/10.1210/er.2011-1050

VITKU J, CHLUPACOVA T, SOSVOROVA L, HAMPL R, HILL M, HERACEK J, BICIKOVA M, STARKA L: Development and validation of LC-MS/MS method for quantification of bisphenol A and estrogens in human plasma and seminal fluid. Talanta 140: 62-67, 2015. https://doi.org/10.1016/j.talanta.2015.03.013

VITKU J, KOLATOROVA L, FRANEKOVA L, BLAHOS J, SIMKOVA M, DUSKOVA M, SKODOVA T, STARKA L: Endocrine disruptors of the bisphenol and paraben families and bone metabolism. Physiol Res 67 (Suppl 3): S455-S464, 2018. https://doi.org/10.33549/physiolres.934005

VOM SAAL FS, HUGHES C: An extensive new literature concerning low-dose effects of bisphenol A shows the need for a new risk assessment. Environ Health Perspect 113: 926-933, 2005. https://doi.org/10.1289/ehp.7713

YANG Y, YIN J, YANG Y, ZHOU N, ZHANG J, SHAO B, WU Y: Determination of bisphenol AF (BPAF) in tissues, serum, urine and feces of orally dosed rats by ultra-high-pressure liquid chromatography-electrospray tandem mass spectrometry. J Chromatogr B Biomed Appl 901: 93-97, 2012. https://doi.org/10.1016/j.jchromb.2012.06.005 